\title{
Maturity of the Warehousing function in Moroccan companies: a case study
}

\author{
Mohamed RAZIK ${ }^{1, *}$, Bouchaib RADI ${ }^{2}$, Chafik OKAR ${ }^{3}$ \\ ${ }^{1}$ Faculty of Sciences and Techniques, University Hassan 1er, Settat, 577, Route de Casablanca, Morocco \\ ${ }^{2}$ Faculty of Sciences and Techniques, University Hassan 1er, Settat, 577, Route de Casablanca, Morocco \\ ${ }^{3}$ School of Technology, University Hassan 1er, 3 Berrechid, 218 Quartier Taqadom Passage d'Alger, Morocco
}

\begin{abstract}
In today's competitive market environment, companies are continuously forced to improve their warehousing operations. To meet high performance goals, tools must be developed to improve efficiency in every aspect of warehousing function. In this paper, we propose a new approach to improve the performance of the warehousing function based on Maturity model, which may better identify, explain, assess and improve this critical function in a supply chain. The aim of this article is to validate the model developed by a case study in a Moroccan company by demonstrating its capacity of assessing the maturity of warehousing function and whether it can develop an improvement roadmap.
\end{abstract}

\section{INTRODUCTION}

Warehousing continue to play an important role in modern supply chains [1]. In today's competitive market environment, companies are continuously forced to improve their warehousing operations [2]. To meet high performance goals of warehousing, a way needs to be found to eliminate any waste from the warehouse, to streamline its operations, and improve efficiency in every aspect of warehousing activities [3].

Many works in various industrial sectors have shown the benefits of using maturity models and the correlation between the improvement of project maturity and project performance (Ibbs \& al 2004 [4], Cooke-davies 2004 [5], Qureshi \& al 2009 [6], Pöppelbuk \& Röglinger 2011 [7]). They promote organizational learning as well as enabling efficient and effective assessment of the performance management practices of the organizations [8]. Their use for self-assessment should result in growth in the maturity levels of performance management practices that should lead to improved levels of performance [8].

However, despite the existence of maturity models for the supply chain (McCormack \& al 2008 [9], Reyes \& al 2010 [10]) and performance measurement systems (Wettstein and Kueng 2002 [11]), there is no specific maturity model for the warehousing function. This is why we propose in this article a new approach to improve the performance of the warehousing function based on Maturity model, which may better identify, explain, assess and improve this critical function in a supply chain.

In this paper, we will describe a maturity model for the warehousing function in Moroccan companies developed using the concept of critical success factors (CSFs). In order to validate and to demonstrate the effectiveness of the proposed Model, we will present a case study in a Moroccan company.

\section{THE WAREHOUSING FUNCTION}

\subsection{The importance of the warehousing function in modern supply chains}

Supply chain management (SCM) has been a major component of competitive strategy to enhance organizational productivity and profitability [12]. They are characterized by many activities and actors that generally pursue conflicting objectives [13]. The correct organization of all the logistic processes and activities that take place within a supply chain node could have a remarkable impact on both processes upstream and

*m.razik@uhp.ac.ma 
downstream the supply chain and on supply chain node internal costs as well [14].

Warehousing have an important role in modern supply chains [15]. A survey of logistics costs in Europe identified the cost of warehousing as being $24 \%$ of total logistics costs [16]. A similar study in the USA, found warehousing costs at $22 \%$ being close to the European figure [17].

As well as being significant in cost terms, warehousing is also important in terms of customer service, it being critical to the success or failure of many supply chains [18]. According to Werling, the role of the warehouse has changed dramatically over the past 30 years, as customer and vendor compliance issues have surfaced and a greater emphasis has been placed on supply chain visibility and customer satisfaction [19].

Warehousing plays a critical role in ensuring high levels of customer service and overall supply chain performance [20]. For logistics managers, the warehouse is at the center of reflections and challenges, as it has become a real factor in optimizing the supply chain. Warehouse management may strongly affect supply chain performances [14]. While there are widely accepted benchmarks for individual warehouse functions such as order picking, little is known about the overall technical efficiency of warehouses [21]. This creates therefore a need for development of tools for assessment the warehousing function for better its performance improvement.

\subsection{The importance of the warehousing function in Moroccan companies}

In Morocco, the awareness of the importance of improving the performance of critical business processes is currently greater. Indeed, The Moroccan Company operates in an environment characterized by a competitive offer increasingly strong requirement for competitiveness increasingly acute and expectations of customers increasingly high [22]. To address these issues and to improve performance and competitiveness, all processes must be improved.

According to (Naciri, 2010), the organization of the supply chain of Moroccan companies generates costs that penalize competitiveness [23]. The links in this chain must be therefore mastered and optimized to gain in overall performance. According to a report by the World Bank and the Ministry of Equipment and Transport of the Kingdom of Morocco in 2006, it was reported that the poor organization of warehousing is one of the obstacles to the development of modern logistics in Morocco [24]. Furthermore and according to a study by the Centre for Transportation Studies for the Western Mediterranean, the level of warehousing services in Morocco is relatively low and the technical conditions under which it occurs are lower than the standards [25].

Particular intention must therefore be given to the performance of the warehousing in Moroccan companies, it is not the construction of warehouses that is difficult, but it is the management of these units that can be problematic because it requires needs in know - how Logistics [23].

On the other hand, Morocco lags far behind in terms of logistics platforms [26]. this delay will be caught up with the national strategy of logistics development by creating a network of logistics centers in different morrocan cities [27]. Once these projects are completed, it will be essential to master the warehousing function for better management and operation of these platforms.

\subsection{Critical Success Factors (CSFs) for warehousing performance improvement}

Across the supply chains, warehousing is an important element of activity in the distribution of goods, from raw materials and work in progress through to finished products. It is not a 'Stand-alone' element of activity and it must not be a weak link in the whole supply chain network [28].

As previously reported, warehousing is costly for enterprises, either in terms of the facilities and equipments required or in terms of human and management resources. Otherwise, the underperformance will risk the achievement of required customer service levels and the maintenance of stock integrity, and result in unnecessarily high costs [28].

Through a previous study [29], we have been determined Critical Success Factors (CSFs) for warehousing performance improvement. We have been classified them into four categories reflecting the four components of the warehousing function defined in our previous study. The table 1 summarizes them:

Table 1. Critical Success Factors (CSFs) for warehousing performance improvement [29]

\begin{tabular}{|c|l|l|}
\hline $\begin{array}{c}\text { Critical Success Factors } \\
\text { for the component } \\
\text { "Design of the }\end{array}$ & - Definition of an optimal location of the Warehouse \\
warehouse" & - Definition of an optimal design of the warehouse \\
& - Definition of warehouse storage capacity \\
\hline
\end{tabular}




\begin{tabular}{|c|c|}
\hline $\begin{array}{l}\text { Critical Success Factors } \\
\text { for the component } \\
\text { "Means for the } \\
\text { warehouse" }\end{array}$ & $\begin{array}{l}\text { - Selection of the appropriate storage systems } \\
\text { - } \quad \text { Selection of the appropriate handling equipment } \\
\text { - } \quad \text { Definition of the necessary and efficient warehouse staff } \\
\text { - } \quad \text { Use of ICTs }\end{array}$ \\
\hline $\begin{array}{l}\text { Critical Success Factors } \\
\text { for the component } \\
\text { "Operations in the } \\
\text { warehouse" }\end{array}$ & $\begin{array}{l}\text { - Definition of a rule for the allocation of products to the functional areas } \\
\text { - Definition of a rule for the allocation of products to the storage areas } \\
\text { - Definition of a policy of picking } \\
\text { - Definition of a policy of delivery } \\
\text { - } \text { Setting a policy for the return processing } \\
\text { - } \text { Optimization of internal logistics for operations in the warehouse }\end{array}$ \\
\hline $\begin{array}{l}\text { Critical Success Factors } \\
\text { for the component } \\
\text { "Management of the } \\
\text { warehouse" }\end{array}$ & $\begin{array}{l}\text { - Definition of inventory management policy } \\
\text { - Definition of the staff allocation procedure to different missions } \\
\text { - Definition of the quality control procedures in the warehouse } \\
\text { - Definition of the security control procedures in the warehouse } \\
\text { - } \text { Formalization of all working procedures } \\
\text { - } \text { Use of a warehouse management information system }\end{array}$ \\
\hline
\end{tabular}

\section{MATURITY WAREHOUSING MOROCCAN COMPANIES}

\subsection{The concept of maturity models}

Firms look increasingly to the development of new tools and models to better manage their projects for ensuring the fulfillment of objectives, for increasing the probability of success, and for ensuring the overall performance of the company. In this context, "more and more organizations are relying on process improvement to improve their probability of success" [30]. The maturity models address the need of process improvement [31].

Maturity describes a "state of being complete, perfect or ready." [32]. To reach a desired state of maturity, an evolutionary transformation path from an initial to a target stage needs to be progressed [33].

The concept of the process maturity was born in the Total Quality Management (TQM) movement and it was widely adopted in "Capability Maturity Model" for software organizations [34]. Then this concept migrated to organizational process and project management [35].

Maturity models act as a structured framework for the revolutionary growth of performance within projects or programmes in organizations. They help in assessing the organizational strengths and weaknesses and in bringing the organization to the next level of maturity or achievement in accordance to the goal to be achieved [36]. They provide means of identifying some crucial steps to be taken, the tasks that are necessary to accomplish and the sequence of events needed to realize significant and quantifiable results [37].

The basic concept of all models is based on the fact that things change over time and that most of these changes can be predicted and regulated [38].

\subsection{Development of a maturity model for the warehousing function in Moroccan companies}

Given the need for a model that assesses the maturity of the warehousing function, and given the absence in the literature of a specific maturity model to this function, we develop in a previous study [39] a preliminary version of a maturity model for warehousing function in Moroccan companies based on the concept of CSFs. The proposed model will be used to identify and exploit the strengths and weaknesses of the warehousing function in Moroccan companies. It will serve as an assessment tool that will improve warehousing performance and consequently that of the supply chain and companies in general.

The structure of the proposed maturity model is built upon the following three dimensions:

1. Maturity level dimension

2. The four main components of the warehousing function;

3. Critical Success Factors (CSFs) for warehousing performance improvement in Moroccan companies.

The first dimension is related to maturity levels, most maturity models measure the maturity through the achievement of some levels range in general from Level 1 to Level 5. In our case, we take a scale of 1 to 3 since we 
propose a new model that is not developed in the literature, and to facilitate its implementation by Moroccan companies:

- Level 1(initial): there is no process area and process is chaotic;

- Level 2 (defined) : is the level where warehousing function processes are documented, standardized, and integrated into a standard implementation process for the organization and;

- Level 3 (managed): warehousing function process and activities are controlled and managed based on quantitative models and tools.

As the performance of the warehousing depends on components related to CSFs presented above, the second dimension of our model will be the four main components of the warehousing function:

- Component 1 : Design of the warehouse,

- Component 2 : Resources for the warehouse,

- Component 3 : Operations in the warehouse

- Component 4 : Management of the warehouse.
The third dimension will be the CSFs for warehousing performance improvement in Moroccan companies.

The calculation of maturity level is as follows:

- The maturity level of the CSF $\mathrm{j}$ for component $\mathrm{i}$ :

$$
>\mathrm{MCSF} \text { ij }
$$

- The maturity level of the component $\mathrm{i}$ :

$$
>\mathrm{M} \text { component } \mathrm{i}=\min (\mathrm{M} \text { CSF } \mathrm{ij})
$$$$
\mathrm{j}=1 \ldots . \mathrm{m}
$$

- The maturity level of the Warehousing function :

$>\mathrm{M}$ Warehousing $=\min (\mathrm{M}$ component $\mathrm{i})$

$$
\mathrm{i}=1 \ldots \mathrm{n}
$$

Based on this principle, we can locally assess the level of maturity and obtain a score for a given CSF, and consequently to a particular component of the warehousing function. The maturity level of a component may not be the same as in the previous one, as CSF for a component are not the same as for another, so the mastery of processes associated with each CSF must be assessed. We describe the proposed maturity model for the warehousing function

\begin{tabular}{|c|c|c|c|c|}
\hline $\begin{array}{c}\text { Component } \\
\text { of the } \\
\text { Maturity } \\
\text { Model For } \\
\text { Warehousing } \\
\text { Function }\end{array}$ & $\begin{array}{l}\text { CSFs for Warehousing } \\
\text { Performance Improvement }\end{array}$ & $\begin{array}{l}\text { Maturity level } 1 \\
\text { (Initial) }\end{array}$ & $\begin{array}{c}\text { Maturity level } 2 \\
\text { (Defined) }\end{array}$ & $\begin{array}{l}\text { Maturity level } 3 \\
\text { (Managed) }\end{array}$ \\
\hline \multirow{5}{*}{$\begin{array}{l}\text { Design of the } \\
\text { warehouse }\end{array}$} & $\begin{array}{l}\text { Definition of an optimal } \\
\text { location of the Warehouse }\end{array}$ & $\begin{array}{l}\text { The location of the } \\
\text { Warehouse is not studied }\end{array}$ & $\begin{array}{l}\text { The location of the } \\
\text { Warehouse is defined }\end{array}$ & $\begin{array}{l}\text { The location of the } \\
\text { Warehouse is defined } \\
\text { optimally }\end{array}$ \\
\hline & $\begin{array}{l}\text { Definition of an optimal } \\
\text { design of the warehouse }\end{array}$ & $\begin{array}{l}\text { The design of the warehouse } \\
\text { is not studied }\end{array}$ & $\begin{array}{l}\text { The design of the warehouse } \\
\text { is defined }\end{array}$ & $\begin{array}{l}\text { The design of the warehouse } \\
\text { is defined optimally }\end{array}$ \\
\hline & $\begin{array}{l}\text { Definition of functional areas } \\
\text { in the Warehouse }\end{array}$ & $\begin{array}{l}\text { The functional areas are not } \\
\text { defined in the Warehouse }\end{array}$ & $\begin{array}{l}\text { The functional areas are } \\
\text { defined in the warehouse }\end{array}$ & $\begin{array}{l}\text { The functional areas are } \\
\text { defined in the warehouse } \\
\text { optimally }\end{array}$ \\
\hline & $\begin{array}{l}\text { Definition of warehouse } \\
\text { storage capacity }\end{array}$ & $\begin{array}{l}\text { The warehouse storage } \\
\text { capacity is not defined }\end{array}$ & $\begin{array}{l}\text { The warehouse storage } \\
\text { capacity is defined }\end{array}$ & $\begin{array}{l}\text { The storage capacity is } \\
\text { considered in the design of } \\
\text { the warehouse }\end{array}$ \\
\hline & $\begin{array}{l}\text { Definition of the } \\
\text { developments of the } \\
\text { warehouse storage capacity } \\
\text { in the future }\end{array}$ & $\begin{array}{l}\text { The evolution of the } \\
\text { warehouse storage capacity in } \\
\text { the future is not defined }\end{array}$ & $\begin{array}{l}\text { The evolution of the } \\
\text { warehouse storage capacity in } \\
\text { the future is defined }\end{array}$ & $\begin{array}{l}\text { The evolution of storage } \\
\text { capacity in the future is } \\
\text { considered in the design of } \\
\text { the warehouse }\end{array}$ \\
\hline \multirow{3}{*}{$\begin{array}{l}\text { Means for the } \\
\text { warehouse }\end{array}$} & $\begin{array}{l}\text { Selection of the appropriate } \\
\text { storage systems }\end{array}$ & $\begin{array}{l}\text { The storage systems are not } \\
\text { used }\end{array}$ & The storage systems are used & $\begin{array}{l}\text { Storage systems used are } \\
\text { optimized }\end{array}$ \\
\hline & $\begin{array}{l}\text { Selection of the appropriate } \\
\text { handling equipment }\end{array}$ & $\begin{array}{l}\text { The handling equipment are } \\
\text { not used }\end{array}$ & $\begin{array}{l}\text { The handling equipment are } \\
\text { used }\end{array}$ & $\begin{array}{l}\text { Handling equipment used are } \\
\text { optimized }\end{array}$ \\
\hline & $\begin{array}{l}\text { Definition of the necessary } \\
\text { and efficient warehouse staff }\end{array}$ & $\begin{array}{l}\text { The warehouse staff is not } \\
\text { defined }\end{array}$ & $\begin{array}{l}\text { The warehouse staff is } \\
\text { defined }\end{array}$ & $\begin{array}{l}\text { The warehouse staff is } \\
\text { defined optimally }\end{array}$ \\
\hline
\end{tabular}
in Moroccan companies in the table 2.

Table 2. Maturity Model for the warehousing function in Moroccan companies [39] 


\begin{tabular}{|c|c|c|c|c|}
\hline & Use of ICTs & $\begin{array}{l}\text { ICTs are not used in the } \\
\text { warehouse }\end{array}$ & $\begin{array}{l}\text { ICTs are used in the } \\
\text { warehouse }\end{array}$ & $\begin{array}{l}\text { ICTs used in the warehouse } \\
\text { are optimized }\end{array}$ \\
\hline \multirow{6}{*}{$\begin{array}{c}\text { Operations in } \\
\text { the } \\
\text { warehouse }\end{array}$} & $\begin{array}{l}\text { Definition of a rule for the } \\
\text { allocation of products to the } \\
\text { functional areas }\end{array}$ & $\begin{array}{l}\text { The allocation of products to } \\
\text { functional areas is done } \\
\text { randomly }\end{array}$ & $\begin{array}{l}\text { A rule for the allocation of } \\
\text { products to the functional } \\
\text { areas is defined }\end{array}$ & $\begin{array}{l}\text { The allocation of products to } \\
\text { the functional areas is } \\
\text { optimized }\end{array}$ \\
\hline & $\begin{array}{l}\text { Definition of a rule for the } \\
\text { allocation of products to the } \\
\text { storage areas }\end{array}$ & $\begin{array}{l}\text { The allocation of products to } \\
\text { the storage areas is done } \\
\text { randomly }\end{array}$ & $\begin{array}{l}\text { A rule for the allocation of } \\
\text { products to the storage areas } \\
\text { is defined }\end{array}$ & $\begin{array}{l}\text { The allocation of products to } \\
\text { the storage areas is optimized }\end{array}$ \\
\hline & $\begin{array}{l}\text { Definition of a policy of } \\
\text { picking }\end{array}$ & $\begin{array}{l}\text { The picking policy is not } \\
\text { defined }\end{array}$ & The picking policy is defined & $\begin{array}{l}\text { The picking policy is } \\
\text { optimized }\end{array}$ \\
\hline & $\begin{array}{l}\text { Definition of a policy of } \\
\text { delivery }\end{array}$ & $\begin{array}{l}\text { The delivery policy is not } \\
\text { defined }\end{array}$ & The delivery policy is defined & $\begin{array}{l}\text { The delivery policy is } \\
\text { optimized }\end{array}$ \\
\hline & $\begin{array}{l}\text { Setting a policy for the return } \\
\text { processing }\end{array}$ & $\begin{array}{l}\text { The return processing policy } \\
\text { is not set }\end{array}$ & $\begin{array}{l}\text { The return processing policy } \\
\text { is defined }\end{array}$ & $\begin{array}{l}\text { The return processing policy } \\
\text { is optimized }\end{array}$ \\
\hline & $\begin{array}{l}\text { Optimization of internal } \\
\text { logistics for operations in the } \\
\text { warehouse }\end{array}$ & $\begin{array}{l}\text { Internal logistics for } \\
\text { operations in the warehouse } \\
\text { is done randomly }\end{array}$ & $\begin{array}{l}\text { A rule for internal logistics } \\
\text { for operations in the } \\
\text { warehouse is defined }\end{array}$ & $\begin{array}{l}\text { Internal logistics for } \\
\text { operations in the warehouse } \\
\text { is optimized }\end{array}$ \\
\hline \multirow{6}{*}{$\begin{array}{c}\text { Management } \\
\text { of the } \\
\text { warehouse }\end{array}$} & $\begin{array}{l}\text { Definition of inventory } \\
\text { management policy }\end{array}$ & $\begin{array}{l}\text { The inventory management } \\
\text { policy is not set. }\end{array}$ & $\begin{array}{l}\text { The inventory management } \\
\text { policy is defined }\end{array}$ & $\begin{array}{l}\text { The inventory management } \\
\text { policy is optimized }\end{array}$ \\
\hline & $\begin{array}{l}\text { Definition of the staff } \\
\text { allocation procedure to } \\
\text { different missions }\end{array}$ & $\begin{array}{l}\text { The staff allocation procedure } \\
\text { for different missions is not } \\
\text { defined }\end{array}$ & $\begin{array}{l}\text { The staff allocation procedure } \\
\text { to different missions is } \\
\text { defined }\end{array}$ & $\begin{array}{l}\text { The staff allocation procedure } \\
\text { to different missions is } \\
\text { optimized }\end{array}$ \\
\hline & $\begin{array}{l}\text { Definition of the quality } \\
\text { control procedures in the } \\
\text { warehouse }\end{array}$ & $\begin{array}{l}\text { The quality control } \\
\text { procedures in the warehouse } \\
\text { are not defined }\end{array}$ & $\begin{array}{l}\text { The quality control } \\
\text { procedures in the warehouse } \\
\text { are defined }\end{array}$ & $\begin{array}{l}\text { The quality control } \\
\text { procedures in the warehouse } \\
\text { are used and improved } \\
\text { continuously }\end{array}$ \\
\hline & $\begin{array}{l}\text { Definition of the security } \\
\text { control procedures in the } \\
\text { warehouse }\end{array}$ & $\begin{array}{l}\text { The s security control } \\
\text { procedures in the warehouse } \\
\text { are not defined }\end{array}$ & $\begin{array}{l}\text { The security control } \\
\text { procedures in the warehouse } \\
\text { are defined }\end{array}$ & $\begin{array}{l}\text { The security control } \\
\text { procedures in the warehouse } \\
\text { are used and improved } \\
\text { continuously }\end{array}$ \\
\hline & $\begin{array}{l}\text { Formalization of all working } \\
\text { procedures }\end{array}$ & $\begin{array}{l}\text { The working procedures in } \\
\text { the warehouse are not defined }\end{array}$ & $\begin{array}{l}\text { The working procedures in } \\
\text { the warehouse are formalized }\end{array}$ & $\begin{array}{l}\text { The formalized working } \\
\text { procedures in the warehouse } \\
\text { are used and improved } \\
\text { continuously }\end{array}$ \\
\hline & $\begin{array}{l}\text { Use of a warehouse } \\
\text { management information } \\
\text { system }\end{array}$ & $\begin{array}{l}\text { A WMS is not used in the } \\
\text { warehouse }\end{array}$ & $\begin{array}{l}\text { A WMS is used in the } \\
\text { warehouse }\end{array}$ & $\begin{array}{l}\text { The WMS used in the } \\
\text { warehouse is optimized }\end{array}$ \\
\hline
\end{tabular}

\section{CASE STUDY: MATURITY OF THE WAREHOUSING FUNCTION IN A MOROCCAN COMPANY}

The proposed model has two objectives: first provide a framework to assess maturity level of warehousing function in Moroccan companies, and second, provide support to companies to develop a roadmap for improving their warehousing functions. To validate our model and examine whether it is suitable for those two uses, we achieve a case study in a Moroccan company. It was created based on an internship with a student engineer in 2015.
We choose SICOTREM Company because its top management needs an action plan to improve the warehousing function. Indeed, SICOTREM suffers from several logistical problems, namely: Delivery delays because of shortages; the work without added value repeated in its warehouse; losses from the current way of managing the warehousing function.

SICOTREM is the Moroccan leader in the production of spikes, wire annealing, wire mesh and galvanized wire. $\mathrm{He}$ has over 40 years of experience in this field and with a production capacity of about 2000 tons / month. 


\subsection{Implementation of the maturity model for the warehousing function}

For the implementation of the maturity model, we propose an evaluation methodology based on questionnaires that will provide the maturity levels for each $\mathrm{CSF}$, and therefore by aggregation for a component, and for the warehousing function. We propose defining a team composed of logistic manager and the responsible for each component to assess, perform the audit and recover as much as possible information for giving a reliable rating for the maturity that best reflects the current state of the warehousing.

The questionnaires are constructed according to the maturity levels defined for each CSF $\mathrm{j}$ (each CSF corresponds to three questions). These questions are generic and can be applied in all components. The difference in the assessment is made by the answers that will depend on the state of the CSF.

For each question, there are three possible answers: yes, no and does not apply. To get the maturity level of a CSF $\mathrm{j}$ for a component $\mathrm{i}, \mathrm{M}$ CSF $\mathrm{ij}$, we compare the responses to maturity scales (ranging from level 1 to 3 ). To obtain it, a positive answer to the question of the same level is necessary, as in most maturity models (CMMI 2006 [79]) it must have completely crossed a maturity level before proceeding to the next.

The results of the evaluation are used to identify areas for improvement in the components of the warehousing function through the comparison between the levels of maturity. When the warehousing function reaches a specified maturity level in a CSF, the improvement roadmap includes the next level. If level 3 is reached, the company must keep it.

\subsection{Maturity of the SICOTREM's Warehousing function}

The maturity level of the SICOTREM's warehousing function is summarized in table 3 as it was assessed by SICOTREM's logistics manager.

Table 3. The maturity level of SICOTREM's Warehousing Function

\begin{tabular}{|c|c|c|c|}
\hline $\begin{array}{l}\text { Component of the } \\
\text { Maturity Model For } \\
\text { Warehousing } \\
\text { Function }\end{array}$ & CSFs for Warehousing Performance Improvement & $\begin{array}{c}\text { Maturity Level } \\
\text { of SICOTREM's } \\
\text { CSFs for } \\
\text { Warehousing } \\
\text { Performance } \\
\text { Improvement }\end{array}$ & $\begin{array}{c}\text { Maturity Level } \\
\text { of SICOTREM's } \\
\text { Component of } \\
\text { the } \\
\text { Maturity Model } \\
\text { For Warehousing } \\
\text { Function } \\
\end{array}$ \\
\hline \multirow{5}{*}{$\begin{array}{l}\text { Design of the } \\
\text { warehouse }\end{array}$} & Definition of an optimal location of the Warehouse & Level 1 & \multirow{5}{*}{ Level 1} \\
\hline & Definition of an optimal design of the warehouse & Level 1 & \\
\hline & Definition of functional areas in the Warehouse & Level 1 & \\
\hline & Definition of warehouse storage capacity & Level 1 & \\
\hline & Definition of the evolution of the warehouse storage capacity in the future & Level 1 & \\
\hline \multirow{4}{*}{$\begin{array}{l}\text { Means for the } \\
\text { warehouse }\end{array}$} & Selection of the appropriate storage systems & Level 1 & \multirow{4}{*}{ Level 1} \\
\hline & Selection of the appropriate handling equipment & Level 2 & \\
\hline & Definition of the necessary and efficient warehouse staff & Level 2 & \\
\hline & Use of ICTs & Level 1 & \\
\hline \multirow{6}{*}{$\begin{array}{c}\text { Operations in the } \\
\text { warehouse }\end{array}$} & Definition of a rule for the allocation of products to the functional areas & Level 1 & \multirow{6}{*}{ Level 1} \\
\hline & Definition of a rule for the allocation of products to the storage areas & Level 1 & \\
\hline & Definition of a policy of picking & Level 1 & \\
\hline & Definition of a policy of delivery & Level 1 & \\
\hline & Setting a policy for the return processing & Level 1 & \\
\hline & Optimization of internal logistics for operations in the warehouse & Level 1 & \\
\hline \multirow{6}{*}{$\begin{array}{c}\text { Management of the } \\
\text { warehouse }\end{array}$} & Definition of inventory management policy & Level 1 & \multirow{6}{*}{ Level 1} \\
\hline & Definition of the staff allocation procedure to different missions & Level 1 & \\
\hline & Definition of the quality control procedures in the warehouse & Level 1 & \\
\hline & Definition of the security control procedures in the warehouse & Level 1 & \\
\hline & Formalization of all working procedures & Level 1 & \\
\hline & Use of a warehouse management information system & Level 1 & \\
\hline \multicolumn{3}{|c|}{ Maturity level of the SICOTREM Warehousing function } & Level 1 \\
\hline
\end{tabular}




\subsection{Roadmap for improving SICOTREM's warehousing performance}

After the assessment of maturity level, based on the proposed model, we developed an improvement roadmap for SICOTREM Company's warehousing function as it is shown in table 4.

Table 4. The improvement roadmap for SICOTREM's Warehousing function

\begin{tabular}{|c|c|c|}
\hline $\begin{array}{l}\text { Component of the } \\
\text { Maturity Model For } \\
\text { Warehousing } \\
\text { Function }\end{array}$ & CSFs for Warehousing Performance Improvement & $\begin{array}{c}\text { Improvement roadmap for SICOTREM's } \\
\text { Warehousing function }\end{array}$ \\
\hline \multirow{5}{*}{$\begin{array}{l}\text { Design of the } \\
\text { warehouse }\end{array}$} & Definition of an optimal location of the Warehouse & The location of the Warehouse must be defined \\
\hline & Definition of an optimal design of the warehouse & The design of the warehouse must be defined \\
\hline & Definition of functional areas in the Warehouse & The functional areas must be defined in the warehouse \\
\hline & Definition of warehouse storage capacity & The warehouse storage capacity must be defined \\
\hline & $\begin{array}{l}\text { Definition of the evolution of the warehouse storage } \\
\text { capacity in the future }\end{array}$ & $\begin{array}{l}\text { The evolution of the warehouse storage capacity in the } \\
\text { future must be defined }\end{array}$ \\
\hline \multirow{4}{*}{$\begin{array}{l}\text { Means for the } \\
\text { warehouse }\end{array}$} & Selection of the appropriate storage systems & $\begin{array}{l}\text { Definition of the storage systems to be used in the } \\
\text { warehouse }\end{array}$ \\
\hline & Selection of the appropriate handling equipment & Optimization of the handling equipment used \\
\hline & Definition of the necessary and efficient warehouse staff & Optimization of the warehouse staff \\
\hline & Use of ICTs & Definition of the ICTs to be used in the warehouse \\
\hline \multirow{6}{*}{$\begin{array}{l}\text { Operations in the } \\
\text { warehouse }\end{array}$} & $\begin{array}{l}\text { Definition of a rule for the allocation of products to the } \\
\text { functional areas }\end{array}$ & $\begin{array}{l}\text { A rule for the allocation of products to the functional } \\
\text { areas must be defined }\end{array}$ \\
\hline & $\begin{array}{l}\text { Definition of a rule for the allocation of products to the } \\
\text { storage areas }\end{array}$ & $\begin{array}{l}\text { A rule for the allocation of products to the storage areas } \\
\text { must be defined }\end{array}$ \\
\hline & Definition of a policy of picking & The picking policy must be defined \\
\hline & Definition of a policy of delivery & The delivery policy must be defined \\
\hline & Setting a policy for the return processing & The return processing policy must be defined \\
\hline & $\begin{array}{l}\text { Optimization of internal logistics for operations in the } \\
\text { warehouse }\end{array}$ & $\begin{array}{l}\text { A rule for internal logistics for operations in the } \\
\text { warehouse must be defined }\end{array}$ \\
\hline \multirow{6}{*}{$\begin{array}{l}\text { Management of the } \\
\text { warehouse }\end{array}$} & Definition of inventory management policy & The inventory management policy must be defined \\
\hline & $\begin{array}{l}\text { Definition of the staff allocation procedure to different } \\
\text { missions }\end{array}$ & $\begin{array}{l}\text { The staff allocation procedure to different missions must } \\
\text { be defined }\end{array}$ \\
\hline & $\begin{array}{l}\text { Definition of the quality control procedures in the } \\
\text { warehouse }\end{array}$ & $\begin{array}{l}\text { The quality control procedures in the warehouse must be } \\
\text { defined }\end{array}$ \\
\hline & $\begin{array}{l}\text { Definition of the security control procedures in the } \\
\text { warehouse }\end{array}$ & $\begin{array}{l}\text { The security control procedures in the warehouse must } \\
\text { be defined }\end{array}$ \\
\hline & Formalization of all working procedures & $\begin{array}{l}\text { The working procedures in the warehouse must be } \\
\text { formalized }\end{array}$ \\
\hline & Use of a warehouse management information system & A WMS must be used in the warehouse \\
\hline
\end{tabular}

\section{Conclusion}

Based on the critical success factors and the concept of maturity, a four-component Maturity Model for the warehousing function in Moroccan companies has been developed. The suggested Maturity Model makes it possible for companies to identify, explain, assess and improve this critical function in a supply chain.

The results obtained from the case study to validate the proposed model are interesting. They allowed assessing the maturity level of the warehousing function and developing a roadmap for improving its performance. Indeed, the diagnostic results confirmed the concern of top management of the company subject of the case study likened to failures of the warehousing function. The "initial level" obtained for the case of this company shows that more actions need to be implemented to achieve higher levels of maturity. The roadmap obtained trace the priority improvements that need to be applied to achieve at least level two of maturity.

For future work, the maturity model suggested should be discussed with other empirical studies in different contexts. 


\section{References}

[1] Baker, P. (2007). An exploratory framework of the role of inventory and warehousing in international supply chains. The International Journal of Logistics Management, 18(1), 64-80.

[2] Ramaa, A., Subramanya, K. N., \& Rangaswamy, T. M. (2012). Impact of warehouse management system in a supply chain. International Journal of Computer Applications, 54(1).

[3] Min, H. (2006). The applications of warehouse management systems: an exploratory study. International Journal of Logistics: Research and Applications, 9(2), 111-126.

[4] Ibbs, C. W., Reginato, J. M., \& Kwak, Y. H. (2004). Developing project management capability: Benchmarking, maturity, modeling, gap analyses, and ROI studies. The Wiley guide to managing projects, 1214-1233.

[5] Cooke - Davies, T. (2004). Project management maturity models. The Wiley guide to managing projects, 1234-1255.

[6] Qureshi, T. M., Warraich, A. S., \& Hijazi, S. T. (2009). Significance of project management performance assessment (PMPA) model. International Journal of Project Management, 27(4), 378-388.

[7] Jens Pöppelbuk, Maximilian Röglinger, "What makes a useful Maturity Model? A Framework of general Design Principals for Maturity Models and Its Demonstration In Business Process Management", ECIS 2011 PROCEEDINGS.

[8] Bititci, U. S., Garengo, P., Ates, A., \& Nudurupati, S. S. (2015). Value of maturity models in performance measurement. International journal of production research, 53(10), 3062-3085.

[9] K. McCormack, MB. Ladeira, and MPV. Oliveira, "Supply Chain Maturity and Performance in Brazil", Supply Chain Management, Vol. 13, No 4, 2008, pp. 272-282.

[10] H.G. Reyes, and R. Giachetti, "Using experts to develop a supply chain maturity model in Mexico", Supply Chain Management, Vol. 15, No. 6, 2010, pp. 415-424.

[11] T. Wettstein, and P. Kueng, "A maturity model for performance measurement systems", in: C.A. Brebbia, P. Pascolo, (Eds.), Management Information Systems GIS and Remote Sensing, WIT Press, Southampton, 2002.

[12] Hong, Y., \& Zhong-Hua, Y. (2013). Supply chain dynamic performance measurement based on BSC and SVM. IJCSI International Journal of Computer Science Issues, 10(1), 271-277.

[13] Labiad, N., Beidouri, Z., \& Bouksour, O. (2012). Evaluation of coordination contracts for a two stage supply chain under prices dependent demand. IJCSI International Journal of Computer Science Issues, 9(1), 151-159.

[14] Longo, F. (2011). Operational Strategies and Internal Logistic Costs Analysis in a Real Warehouse Based on Modeling \& Simulation. IJCSI International Journal of Computer Science Issues, Vol. 8, Issue 4, No 1, 39-47.

[15] Baker, P. (2007). An exploratory framework of the role of inventory and warehousing in international supply chains. The International Journal of Logistics Management, 18(1), 64-80.

[16] European Logistics Association / AT Kearney (2004), Differentiation for Performance, Deutscher Verkehrs-Verlag $\mathrm{GmbH}$, Hamburg.
[17] Establish Inc / Herbert W. Davis \& Co. (2005), Logistics Cost and Service 2005. Council of Supply Chain Management Professionals Conference presentation. Accessed at www.establishinc.com on 23rd August 2006.

[18] Frazelle, E.H. (2002), Supply Chain Strategy: the Logistics of Supply Chain Management, McGraw-Hill, New York.

[19] Werling, Chris. (2006). Tomorrows Warehouse, Corner Stone Solutions, Inc.

[20] Öztürkoğlu, Ö., Gue, K. R., \& Meller, R. D. (2014). A constructive aisle design model for unit-load warehouses with multiple pickup and deposit points. European Journal of Operational Research, 236(1), 382-394.

[21] Johnson, A., \& McGinnis, L. (2010). Performance measurement in the warehousing industry. IIE Transactions, 43(3), 220-230

[22] Les Guides CGEM: Guide de la qualité pour les PME-PMI. (December 2009).

[23] Naciri, A. B. (2010). La contribution de la logistique à l'intégration des sous-traitants marocains du secteur textilehabillement à la logique des donneurs d'ordre étrangers. Repenser les économies africaines pour le développement, 121.

[24] La Logistique du Commerce et la Compétitivité du Maroc. Banque Mondiale \& Ministère de l'Equipement et du Transport. (Mai, 2006).

[25] Le secteur logistique sur la rive sud de la Méditerranée Occidentale. CETMO. (2010).

[26] Balambo, M. A., \& Houssaini, A. (2011). Typologies d'intégration des Supply Chains: perspectives pour le contexte Marocain. In LES DEFIS DU MANAGEMENT INTERNATIONAL A L'AUBE DU XXIème SIECLE (p. 21).

[27] Stratégie Nationale de développement de la compétitive logistique. Ministère de l'équipement, du transport et de la logistique, Maroc. (2010).

[28] Mohan, V. E. (2012). Warehousing and Inventory Management. CII Institute of Logistics. Chennai: www. ciilogistics.com.

[29] Razik, M., Radi, B. \& Okar, C. (2016). Les facteurs clés de succès pour l'amélioration de la performance de la fonction entreposage au sein des entreprises marocaines. Ouvrage collectif "Management logistique au Maroc".

[30] Basque R. - 2004 - « CMMI : Un itinéraire fléché vers le Capability Maturity Model Intregration » - Dunod

[31] Patnayakuni, R., Rai, A. \& Tiwana A. - 2007 - « Systems Development Process Improvement: A Knowledge Integration Perspective »

[32] Simpson, J.A. and E.S.C. Weiner, The Oxford English Dictionary. 2 ed. 1989, Oxford, UK: Oxford University Press.

[33] Fraser, P., J. Moultrie, and M. Gregory, The Use of Maturity Models/Grids as a Tool in Assessing Product Development Capability. in IEEE IEMC 2002. 2002. Cambridge, UK.

[34] Chafik Okar, Zitouni Beidouri, Said Mssassi, Said Barrijal, "A maturity model for SCPMS project: an empirical investigation in large sized Moroccan companies", IJCSI International Journal of Computer Science Issues, Vol. 8, Issue 2, March 2011 ISSN (Online): 1694-0814 www.IJCSI.org. 
[35] T. J. Cooke-davies, and A. Arzymanowc, "The maturity of project management in different industries an investigation into variations between project management models", International Journal of Project Management, Vol. 21, 2003, pp. 471-478.

[36] S. B. Abd Karim1, R. Adawiyah, A. Rahmi, M. Suhaimi Mohd Danuri3, O. Mohamed, "Developing the Value Management Maturity Model (VM3C)”, Journal of Design and Built Environment Vol. 14(1), June 2014.

[37] A. F. Bay, and M. Skitmore, "Project management maturity: some results from Indonesia", Journal of Building and Construction Management, Vol. 10, 2006, pp. 1-5].

[38] Irena Hribar Rajterič, "Overview of Business Intelligence Maturity Models", Management, Vol. 15, 2010, 1, pp. 47-67

[39] Razik, M., Radi, B. \& Okar, C. (2016). Vers un model de maturité de la fonction entreposage chez les entreprises marocaines. Conférence Journée doctorants FST de Settat. Mai 2016. 